\title{
Defective Concanavalin A-Induced Suppression in Bancroftian Filariasis
}

\author{
C.R. Vanamala, P.R. Narayanan \\ Tuberculosis Research Centre, Madras, India
}

\begin{abstract}
A concanavalin-A-induced suppressor cell assay was carried out in 10 patients with chronic filarial disease, 13 asymptomatic microfilaria carriers and 7 healthy subjects. Both the chronic filarial patients and the asymptomatic microfilaria carriers showed statistically significant reduced suppression indices when compared with the control subjects. The reduction in suppression indices was greater in the microfilaria carriers than in the chronic filarial patients.
\end{abstract}

\section{Introduction}

Much evidence has accumulated in the past to indicate that concanavalin A (Con A) stimulation of human lymphocytes produces suppressor activity [Shou et al., 1976; Sakane and Green, 1977]. Con A has been shown to polyclonally activate suppressor cells in vitro, which are then able to inhibit the response of autologous lymphocytes to mitogens. Though a number of previous reports have questioned the validity of this assay [Feighery et al., 1978; Fernandes and Mac Sween, 1980], it is clear from the recent work of Knaab and Jeannet [1983] and Meroni et al. [1983] that true suppression is responsible for the observed inhibition of the responses to Con A and that this assay can be used to assess the functional ability of suppressor cells in different clinical situations. The present studies were designed to investigate the role of Con-A-induced suppressor activity in human filariasis. Suppressor cells were generated from peripheral blood lymphocytes by pretreatment with Con A. The suppressive effects of these cells were assayed on the mitogenic responses of autologous responder lymphocytes derived from normal subjects and filarial patients.

\section{Materials and Methods}

\section{Patients}

Patients for the study were chosen from those attending the Filariasis Clinic of the Government General Hospital, Madras, India.
Twenty-three patients comprising 13 microfilaraemics and 10 chronic patients were admitted to the study. The clinical history of the patients is summarized in table I. In addition, 7 normal healthy volunteers were included as controls.

\section{Isolation of Lymphocytes}

Citrated blood was layered on lymphocyte separation medium (Bionetics Laboratory Products, Litton Bionetics, Kentington, Md.). The cells were subsequently washed thrice in Hanks's balanced salt solution and resuspended in RPMI 1640 medium containing $10 \%$ heat-inactivated pooled $\mathrm{AB}$ serum with antibiotics. The lymphocytes were suspended in a final concentration of $1 \times 10^{6}$ cells $/ \mathrm{ml}$.

\section{Mitogen Preparation}

Con A was dissolved in RPMI 1640 medium at a concentration of $1 \mathrm{mg} / \mathrm{ml}$ and then sterilized by filtration through Millipore. Fresh dilutions of Con A were used for each experiment.

\section{Generation of Suppressor Cells}

Essentially an autologous system was designed whereby the responder and Con-A-pretreated stimulator cells were derived from the same individual.

Con A Pretreatment of Lymphocytes

Batches of $1 \times 10^{6} / \mathrm{ml}$ of lymphocytes were cultured in the presence of varying concentrations of Con A for $40 \mathrm{~h}$.

\section{Suppressor Assay}

One batch each of autologous Con-A-pretreated and nonstimulated lymphocytes $\left(1 \times 10^{6}\right.$ cells $\left./ \mathrm{ml}\right)$ were incubated with mitomycin $\mathrm{C}, 20 \mu \mathrm{g} / \mathrm{ml}$, at $37^{\circ} \mathrm{C}$ for $45 \mathrm{~min}$. The mitomycin-C-treated and the responder lymphocytes were washed thrice with Hanks's balanced salt solution and resuspended in RPMI 1640 medium containing $10 \%$ heat-inactivated pooled $\mathrm{AB}$ serum to a concentration of $1 \times 10^{6}$ cells $/ \mathrm{ml}$. Triplicate cultures were set up containing $1 \times 10^{5}$ responder lymphocytes and either: (a) $1 \times 10^{5}$ Con-A-pretreated mi- 
Table I. Clinical and parasitological status of the study population

\begin{tabular}{llll}
\hline $\begin{array}{l}\text { Study } \\
\text { groups }\end{array}$ & $\begin{array}{l}\text { No. } \\
\text { of } \\
\text { indivi- } \\
\text { duals }\end{array}$ & Clinical status & $\begin{array}{l}\text { Microfilaraemia } \\
\text { No. of microfilaria/ } \\
\text { milliliter blood } \\
\text { range }\end{array}$ \\
\hline Controls & 7 & $\begin{array}{l}\text { voluntary blood } \\
\text { donors without } \\
\text { any evidence of } \\
\text { filariasis }\end{array}$ & nil \\
Chronic & 10 & $\begin{array}{l}\text { filarial patients } \\
\text { with chronic } \\
\text { symptoms like } \\
\text { irreversible oedema } \\
\text { of long duration and } \\
\text { elephantiasis }\end{array}$ & nil \\
Microfilar- & & $\begin{array}{l}\text { no clinical symptoms } \\
\text { of filariasis }\end{array}$ & $10-500$ \\
\hline
\end{tabular}

tomycin-C-treated lymphocytes, or (b) $1 \times 10^{5}$ unstimulated mitomycin-C-treated lymphocytes.

One of three concentrations of Con A was added to these cultures which were then incubated at $37^{\circ} \mathrm{C}$ in a $\mathrm{CO}_{2}$ incubator and harvested on day 3 with prior addition of ${ }^{3} \mathrm{H}$-thymidine during the last $18 \mathrm{~h}$.

The percentage inhibition of the blastogenic response was expressed according to the formula given below:

$$
\text { index }=1-\frac{\begin{array}{c}
\text { mean cpm of stimulated cultures containing } \\
\text { suppressor cells - mean cpm of unstimulated } \\
\text { cultures containing suppressor cells }
\end{array}}{\begin{array}{c}
\text { mean cpm of stimulated cultures containing } \\
\text { control cells - mean cpm of unstimulated } \\
\text { cultures containing control cells }
\end{array}} \times 100 \text {. }
$$

\section{Results}

Three different concentrations $(5,20$ and $50 \mu \mathrm{g} /$ $\mathrm{ml}$ ) of Con A were used in the first culture to generate suppressor cells. All three doses were equally effective

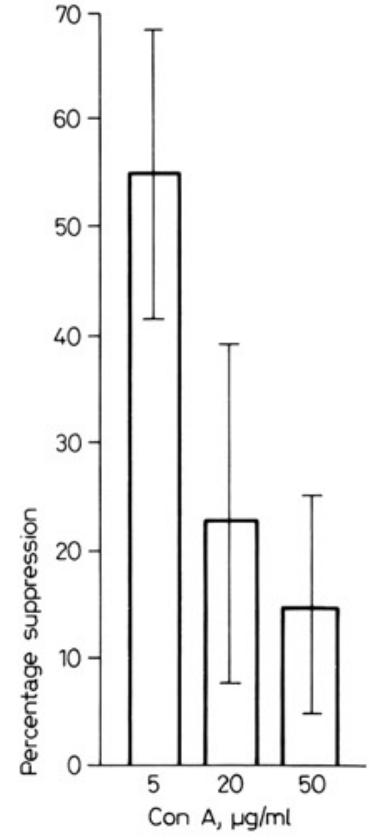

Fig. 1. Changes observed in suppression indices using various doses of Con A in the second culture. Suppressor cells were preactivated with $5 \mu \mathrm{g} / \mathrm{ml}$ Con A and tested with responders at the ratio of $1: 1$. Values represent the mean $\pm \mathrm{SD}$ of 7 control subjects tested.

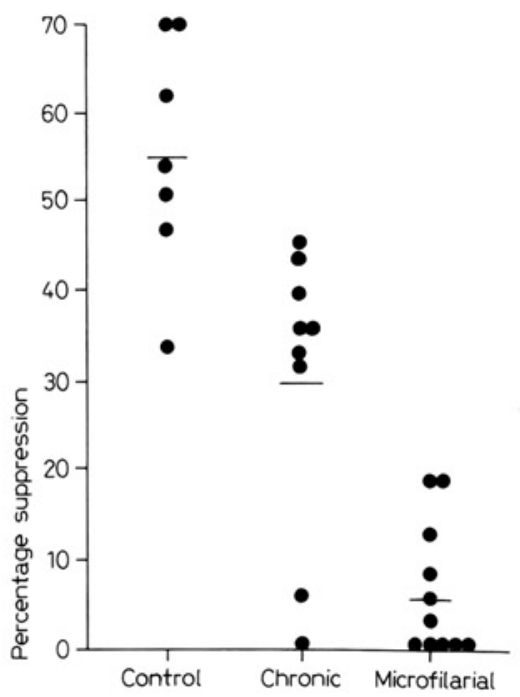

Fig. 2. Suppression indices in healthy subjects and in filarial patients. Significance of difference between groups by Student's t test: normal versus chronic filarial patients: $p<0.01$; normal versus microfilaria carriers: $\mathrm{p}<0.001$; chronic versus microfilaria carriers: $\mathrm{p}<0.001$. 
Table II. Effect of Con-A-pretreated peripheral blood lymphocytes on stimulation of autologous peripheral blood lymphocytes with Con A

\begin{tabular}{|c|c|c|c|c|c|c|}
\hline \multirow[t]{2}{*}{ Subjects } & \multirow[t]{2}{*}{$\begin{array}{l}\text { Responding } \\
\text { cells }\end{array}$} & \multicolumn{2}{|c|}{$\begin{array}{l}\text { Mitomycin-C-treated } \\
\text { cells preincubated with }\end{array}$} & \multirow[t]{2}{*}{ Con A } & \multirow[t]{2}{*}{$\begin{array}{l}\text { Response } \\
\text { cpm } \pm \text { SD }\end{array}$} & \multirow{2}{*}{$\begin{array}{l}\text { Percentage } \\
\text { of } \\
\text { suppression }\end{array}$} \\
\hline & & none & Con A & & & \\
\hline \multirow{4}{*}{$\begin{array}{l}\text { Healthy volunteers } \\
\qquad n=7\end{array}$} & + & + & - & - & $2,244 \pm 1,290^{\mathrm{b}}$ & \multirow{4}{*}{55} \\
\hline & + & + & - & + & $33,284 \pm 19,776$ & \\
\hline & + & - & + & - & $4,657 \pm 3,908^{b}$ & \\
\hline & + & - & + & + & $18,726 \pm 11,502$ & \\
\hline \multirow{4}{*}{$\begin{array}{l}\text { Chronic filarial } \\
\text { patients } \\
n=8^{\mathrm{c}}\end{array}$} & + & + & - & - & $1,872 \pm 798^{b}$ & \\
\hline & + & + & - & + & $24,152 \pm 10,862$ & \multirow{3}{*}{32} \\
\hline & + & - & + & - & $2,583 \pm 1,182^{b}$ & \\
\hline & + & - & + & + & $17,754 \pm 10,208$ & \\
\hline \multirow{4}{*}{$\begin{array}{l}\text { Asymptomatic } \\
\text { microfilaria carriers } \\
\mathrm{n}=11\end{array}$} & + & + & - & - & $2,213 \pm 3,943^{b}$ & \multirow{4}{*}{6.3} \\
\hline & + & + & - & + & $33,638 \pm 18,411$ & \\
\hline & + & - & + & - & $3,013 \pm 2,805^{\mathrm{b}}$ & \\
\hline & + & - & + & + & $32,293 \pm 16,158$ & \\
\hline $\begin{array}{l}\text { a For suppression index } \\
\text { b cpm of unstimulated }\end{array}$ & $\begin{array}{l}\text { cpm values } w \\
\text { tures. }\end{array}$ & ised. & & & & \\
\hline c One patient showed $n$ & uppression. & & & & & \\
\hline
\end{tabular}

in generating a high suppression index. The concentration of $5 \mu \mathrm{g} / \mathrm{ml}$ was then chosen because of the presence of high background levels in unstimulated co-cultures containing Con-A-pretreated cells activated with higher doses of Con A, presumably due to a carry-over effect of Con A. $5 \mu \mathrm{g} / \mathrm{ml}$ Con A gave more suppression than 20 or $50 \mu \mathrm{g} / \mathrm{ml}$ when used in the second culture (fig. 1). Hence, the experiments were carried out using a concentration of $5 \mu \mathrm{g} / \mathrm{ml}$ both in the first and second cultures.

Peripheral blood lymphocytes from 7 normal healthy control subjects showed effective suppressive activity with a degree of suppression in the range of $34-70 \%$. Two out of nine chronic filarial patients showed little or no suppression (nil and 7\%) and the degree of suppression in the remaining 7 ranged between 32 and $45 \%$.

Eleven subjects with circulating microfilariae in their night blood examination were also studied. In contrast to both normal and chronic groups, none of the 11 subjects showed a degree of suppression of more than $18 \%$. Five of these subjects did not show any suppression at all (fig. 2). One out of ten chronic filarial patients and 2 out of 13 asymptomatic microfilaria carriers showed a high suppression index of $67 \%$ when tested by Con A, $5 \mu \mathrm{g} / \mathrm{ml}$, both in the first and second cultures. But all the 3 patients showed a reduced suppression index when tested by using a different Con A concentration (data not shown).

\section{Discussion}

In our previous studies, we observed that the in vitro proliferative response of peripheral blood lymphocytes from adult filarial patients to Con A was reduced, as compared to the control subjects. This reduced response could not be attributed to either adherent suppressor cells, antigen-induced suppressor cells, short-lived suppressor cells, or inhibitory serum factors [Narayanan et al., 1986].

Immunosuppression due to $\mathrm{T}$ lymphocytes has been implicated in filariasis by Ottesen et al. [1977]. Evidence for the presence of suppressor $\mathrm{T}$ lymphocytes in human filarial patients has also been presented by Piessens et al. [1982]. They reported an increased number of suppressor T cells in 15 out of 17 patients with Brugia malayi microfilaraemia and 6 out of 11 patients with elephantiasis.

Our present study demonstrates that peripheral 
blood lymphocytes from subjects with circulating (Wuchereria bancrofti) microfilariae and chronic filarial patients exhibit a decreased suppression index in the Con A suppressor cell assay compared to control subjects. The differences between control subjects and chronic patients $(\mathrm{p}<0.01)$, control and microfilaria carriers $(\mathrm{p}<0.001)$ and chronic and microfilaria carriers $(\mathrm{p}<0.001)$ are highly significant. Thus, the present study documents an association between the clinical status of patients and an alteration in response of $\mathrm{T}$ lymphocytes, as tested by a well-established Con A suppressor cell assay.

The decreased suppressor function measured in the filarial patients could have been due to a decreased state of activity of the subset of suppressor cells regulating Con-A-induced mitogenesis or to a decrease in the number of these cells or both. It is also possible that the decreased Con-A-induced suppression found in our study occurred in response to a succeeding phase of intensified immunological reactivity in the human host. For example, in the presence of circulating microfilaria there might be a heightened immune attack directed against an antigen, resulting in an enhancement of number and function of suppressor activity. The presence of a pre-existing hyperreactive suppressor mechanism due to suppressor $\mathrm{T}$ cells induced by the parasite may limit further induction of suppressor cells in vitro. Though the increased or lower degree of Con A suppression using a similar assay has been related to the pathogenesis of leprosy [Nath et al., 1979] and systemic lupus erythematosus patients [Kaufman and Boswick, 1979], the exact relationship between suppressor activity and filariasis is unknown. But, it is clear from this study that there is perturbation of regulatory $\mathrm{T}$ cells, and this perturbation occurs to some extent in filarial patients, but more prominently in asymptomatic carriers.

Further investigation of Con-A-induced suppressor cells may help to define the immune mechanisms involved in filariasis and their importance.

\section{Acknowledgements}

We thank Dr. R. Prabhakar for his keen interest and support, Dr. Eric A. Ottesen and Dr. Tom B. Nutman for their discussions, Dr. V. Kumaraswami and Dr. C.B. Sanjeevi for collection of blood samples, Mr. J. Jayaraj for the technical assistance and Mr. P. Karthigayan for typing the manuscript.

\section{References}

Feighery, C.; Whelan, C.A.; Weir, D.G.; Greally, J.R.: In vitro studies of suppressor cell function in human peripheral blood mononuclear cells. Clin. exp. Immunol. 32: 459-465 (1978).

Fernandes, L.A.; Mac Sween, J.M.: Generation of suppressor cells by concanavalin A; a new perspective. J. Immun. 125: 267-269 (1980).

Kaufman, D.B.; Botswick, E.: Defective suppressor T cell activity in systemic lupus erythematosus. Clin. Immunol. Immunopathol. 13: 9 (1979).

Knaab, S.; Jeannet, M.: A re-evaluation of concanavalin A induced suppressor cell assay in man. Int. Archs Allergy appl. Immun. 71: 97-102 (1983).

Meroni, P.L.; Balestricri, G.; Barcellini, W.; DeBartolo, G.; Fenni, G.; Tincani, A.; Zanum, C.: Con A suppressor cell assay; a further characterisation. J. clin. Lab. Immunol. 10: 159-163 (1983).

Narayanan, P.R.; Vanamala, C.R.; Alamelu, R.; Kumaraswamy, V.; Tripathy, S.P.: Reduced lymphocyte response to mitogens in patients with bancroftian filariasis. Trans. R. Soc. trop. Med. Hyg. 80: 78-84 (1986).

Nath, I.; Narayanan, R.B.; Mehra, N.K.; Sharma, A.K.; Gupte, M.D.: Con A induced suppressor activity in human leprosy. J. clin. Lab. Immunol. 2: 319-324 (1979).

Ottesen, E.A.; Weller, P.R.; Heck, L.: Specific cellular immune unresponsiveness in human filariasis. Immunology 33: 413-421 (1977).

Piessens, W.F.; Partano, F.; Hoffman, S.L.; Ratiwayanto, S.; Piessens, P.W.; Palmieri, J.R.; Koiman, I.; Dennis, D.T.; Carney, W.P.: Antigen specific suppressor $\mathrm{T}$ lymphocytes in human lymphatic filariasis. New Engl. J. Med. 307: 144-148 (1982).

Sakane, T.; Green, I.: Human suppressor T cells induced by Con A. Suppressor T cells belong to distinctive T cell subclasses. J. Immun. 119: 1169-1178 (1977).

Shou, L.; Schwarte, S.A.; Good, R.A.: Suppressor cell activity after concanavalin A treatment of lymphocytes from normal donors. J. exp. Med. 143: 1100-1110(1976).

Received: August 13,1986

Correspondence to: Dr. P.R. Narayanan, Deputy Director (Immunology),

Tuberculosis Research Centre,

Spur Tank Road, Chetput,

Madras 600031 (India)
@ For permitted use only. ANY FURTHER DISTRIBUTION OF THIS ARTICLE REQUIRES WRITEN PERMISSION FROM S. KARGER AG BASEL AND MAY BE SUBJECT TO A PERMISSION FEE 